\title{
SAURAUIA TAYLORII (ACTINIDIACEAE), A DISTINCTIVE NEW SPECIES FROM THE KAIJENDE HIGHLANDS OF PAPUA NEW GUINEA
}

\author{
W. TAKEUCHI \\ Arnold Arboretum and the Herbaria of Harvard University, c/o PNG National Forest Authority, \\ P.O. Box 314, Lae, Morobe Province 411, Papua New Guinea
}

\section{SUMMARY}

Saurauia taylorii is described from subalpine environments in the Kaijende Highlands of Enga Province. The new species is easily distinguished by its unusually small and glabrous leaf-blades, and by its nodding flowers.

Key words: Saurauia taylorii, Papua New Guinea, Wildlife Management Area.

\section{INTRODUCTION}

The Kaijende Highlands is a locality of considerable resource significance to Papua New Guinea (PNG). As the socioeconomic centre for Enga Province, the district ironically includes some of the largest remaining tracts of upper montane forest in Papuasia. Its open-pit mine at Porgera is the world's sixth largest producer of gold (Fig. 1), averaging

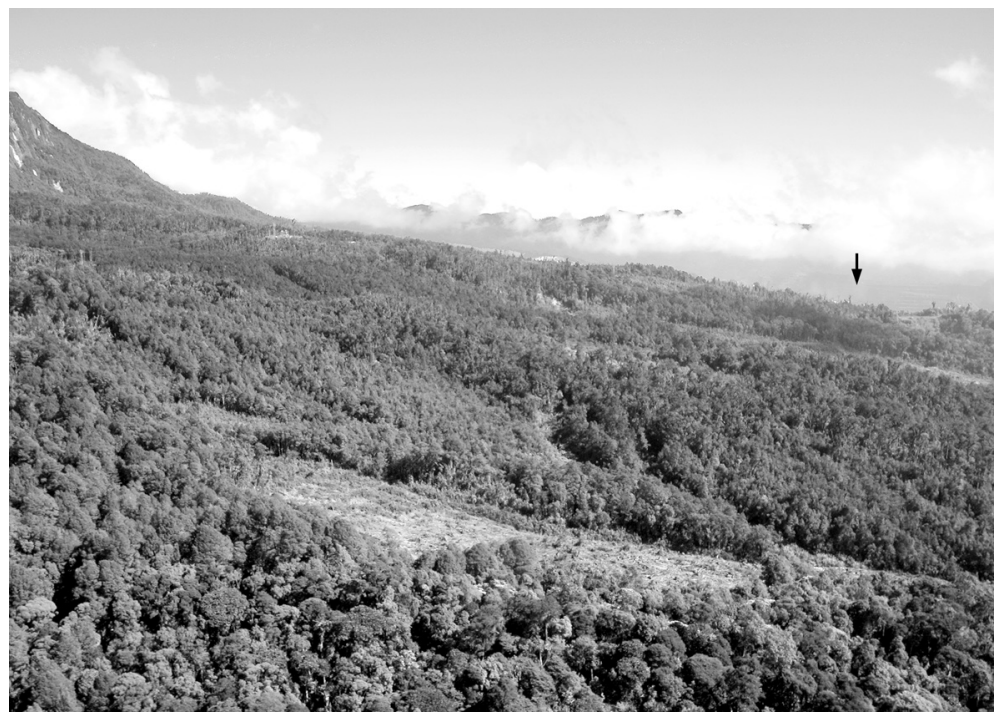

Fig. 1. Kaijende Highlands. Foreground: forest habitat for Saurauia taylorii. Background (arrow): the Porgera open pit, one of the world's premier gold mines. 


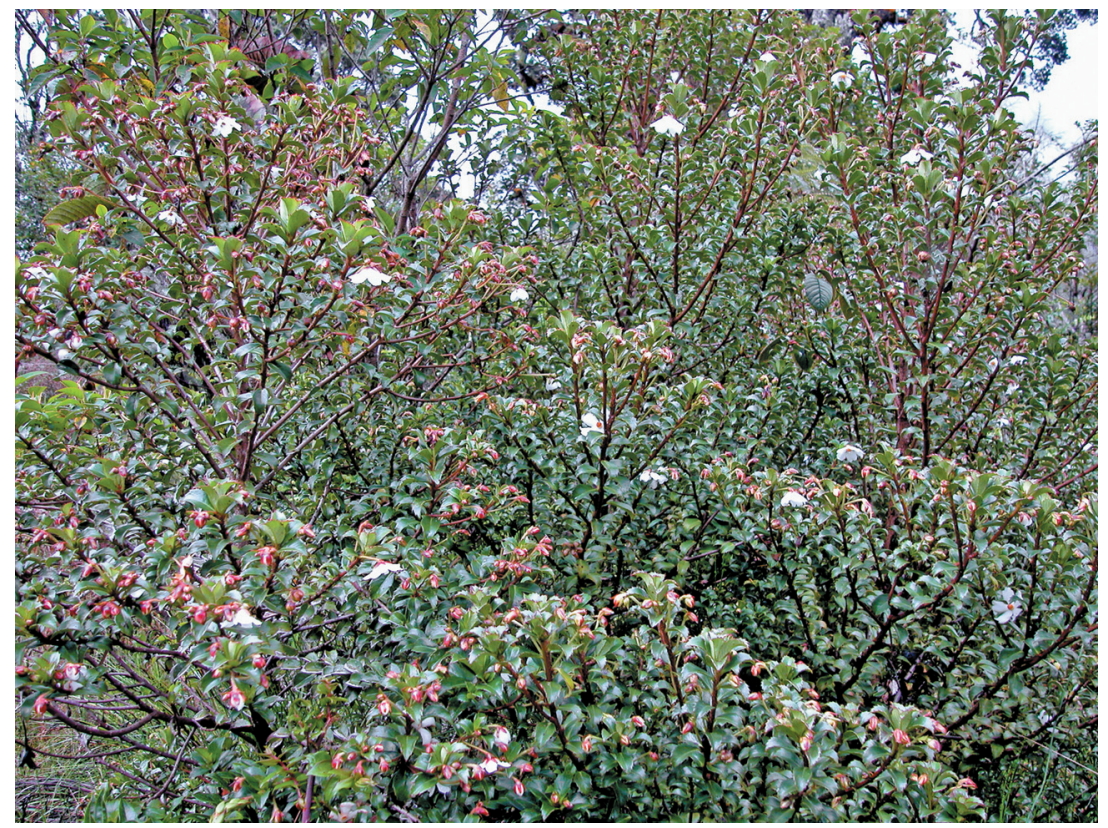

Fig. 2. Saurauia taylorii W.N.Takeuchi. In situ flowering aspect (Takeuchi, Towati \& Ama 20310).

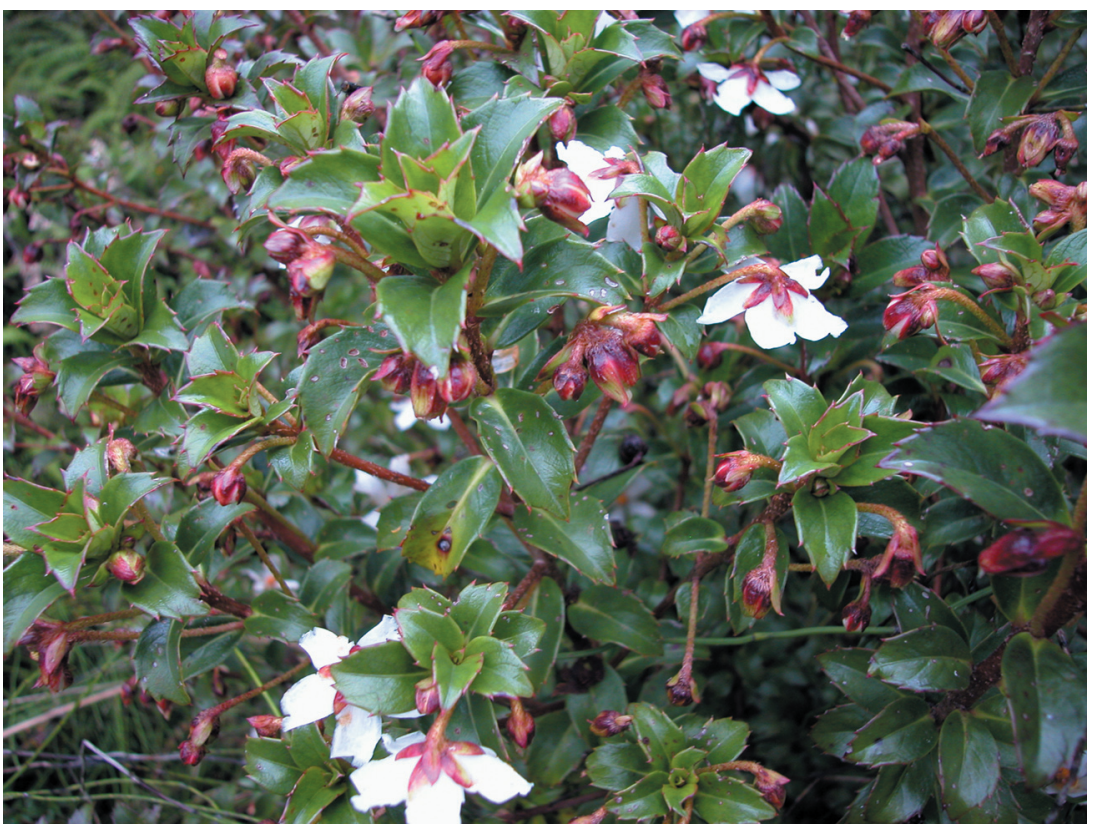

Fig. 3. Closer view of the flowering branches. The corolla is disproportionately large in relation to the unusually small (1.5-3 cm long) leaf-blades (Takeuchi, Towati \& Ama 20310). 
over a million ounces of precious metal per year and generating $15 \%$ of PNG's export earnings (ABN-AMRO Morgans 2006). Pristine environments adjacent to the gold mine are currently being considered for conservation action as a Wildlife Management Area (WMA) jurisdiction (Richards 2007).

The mountainous region between Mt Wilhelm and Kaijende encompasses one of the planet's five richest concentrations of vascular plants (Barthlott et al. 1996, 2005). In recognition of probable ecosystem values, Conservation International has instituted a long-term plan of biotic exploration focused on the Indonesian-PNG cordillera and adjoining colline zone, with a nascent Porgera-based WMA at its eastern endpoint. The Kaijende Highlands Expedition of 2005 was the lead operation in this projected binational agenda. The following account is the latest in a series of publications presenting floristic discoveries from that undertaking.

\section{DESCRIPTION}

\section{Saurauia taylorii W.N.Takeuchi, spec. nov. - Fig. 2, 3; Map 1}

Saurauiae emarginatae similis, foliis glabris minoribus $14-29(-34) \mathrm{mm}$ longis differt. - Typus: Takeuchi, Towati \& Ama 20310 (holo LAE; iso A, L), Papua New Guinea, Enga Province, Waile Creek, alt. 3200 m, 9 September 2005.

Terrestrial shrubs $0.5-3 \mathrm{~m}$ tall, crowns compact, rounded. Branchlets corymbiform, crowded, unarmed, subapical axes 1.5-2 mm diam., compressed, striate, older axes cylindrical, without lenticels; scales striguliform, (1-)2-4 mm long, pallescent, \pm dense, subpersistent; hair indument absent; surfaces dull black or dark brown, discolorously marked by the remnants of fallen scales; internodes $1-9(-15) \mathrm{mm}$. Leaves spiral, spreading, glabrous; petioles 1-2.5(-3) mm long, pulviniform, black, broadly channelled on the upper side; lamina elliptic, elliptic-ovate, or obovate, 14-29(-34) by $5-15(-19) \mathrm{mm}$, coriaceous; adaxially striate-rugulose, nitid, black or fuscous after drying; abaxially pustulate, dull brown; base cuneate to obtuse, symmetrical; margins coarsely serrate in the upper $1 / 2-2 / 3$, entire below, serrations (3-) $5-8$ per side, each with an acroscopic spine, these marginal spines conoid-vasiform, 1-1.5 mm long, pale brown, smooth; apex acute, spinescent; venation brochidodrome, secondaries in 6-9 pairs, arcuate, at the lamina centre diverging $40-60^{\circ}$ from midribs, supramedially reticulating, crossing nerves lax, subscalariform, veins adaxially obscure or planate, abaxially prominent, discolorous. Inflorescence axillary from foliate nodes, ascending; peduncles (15-)21-42 mm long, angulate (or terete), lineate, black, subdensely clothed with appressed scales similar to the branchlet indument; pedicels (if present) 1-11 mm long; bracts elliptic-ovate, (3.5-)6.5-9 by 1-3 mm, paired, closely subtending calyces or 1-5(-10) mm distant, in multiflorous inflorescences also present at the peduncle apex, induplicative or not, glabrous. Flowers solitary or monochasial, nodding, bisexual; sepals 5, narrowly ovate, $7-9$ by $3-4 \mathrm{~mm}$, connate in the basal $1 \mathrm{~mm}$, concave, entire, with or without a hyaline border, adaxially glabrous, abaxially provided with appressed bristle-hairs along the centreline and near the base; petals 5, free or nearly so, obovate-spathulate, $14-17$ by $7-9 \mathrm{~mm}$, retuse, venose, bifacially glabrous, marked by linear cystoliths or not; stamens $70-76,4$ - or 5-seriate, adnate to petals, 


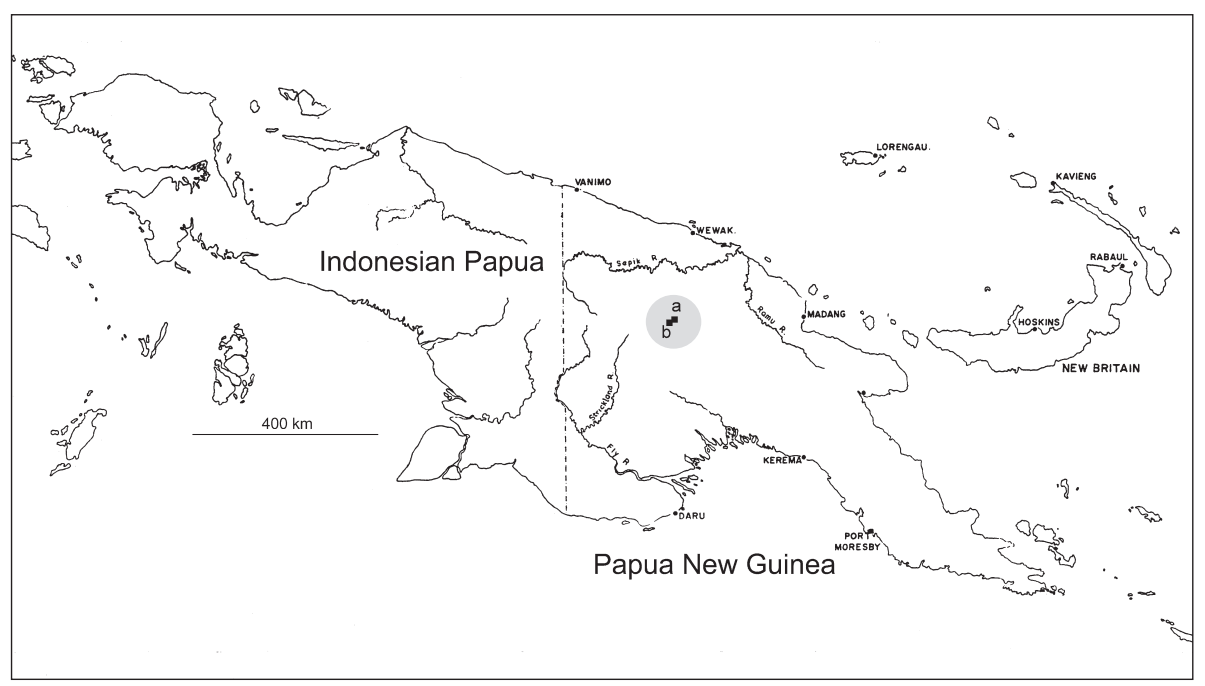

Map 1. Island of New Guinea. Localities from the Kaijende Expedition of 2005. a. Porgera; b. Waile Creek.

glabrous; filaments compressed or flat, $1 \mathrm{~mm}$ long; anther-cells 2, linear-elliptic, 3.2 by $0.4 \mathrm{~mm}, \pm$ basifixed, introrse, longitudinally dehiscent, obscurely calcarate at the base; connective ligulate, apically excurrent to a linear-deltate process c. $0.2-0.3 \mathrm{~mm}$ long; ovary superior, globular-umbonate, $2 \mathrm{~mm}$ diam., densely covered by pale villous hairs, locules 4 (or 5); styles 4 (or 5), $5 \mathrm{~mm}$ long, glabrous, black, fused in the lower 2-2.5 mm into a sulcate column, distally spreading, stigma punctiform. Fruit (immature) a dry berry, subglobose, $7 \mathrm{~mm}$ diam., crowned by the stigmatic remnant, indument persisting from the ovary, fruiting sepals not accrescent.

Field notes - Lamina fleshy or firm, adaxially dark green, abaxially pale green; peduncles ascending; flowers nodding, sepals red, petals white.

Distribution - Known only from the Kaijende Highlands of Enga Province, near the Porgera gold mine.

Habitat \& Ecology - In mossy montane forests and in transitional border communities between subalpine forest and grassland. Occurring in mixed populations with Saurauia altiterra, S. giluwensis (Fig. 4), and S. trugul, primarily at 2900-3100 m altitude.

Etymology - The new species is named after fisheries biologist Garth Taylor, a former President of the environmental consulting group PT Hatfield Indonesia (Bogor, Indonesia), and the writer's colleague on previous multidisciplinary biosurveys in Sumatra and Irian Jaya.

Notes -1 . The most recent treatment for New Guinea (Diels 1922) is acutely outdated. Van Royen's (1982) review covers only nine species from elevations above $3000 \mathrm{~m}$. Many of the c. 50 New Guinean species are range-restricted, particularly those from montane environments (Smith 1941). 


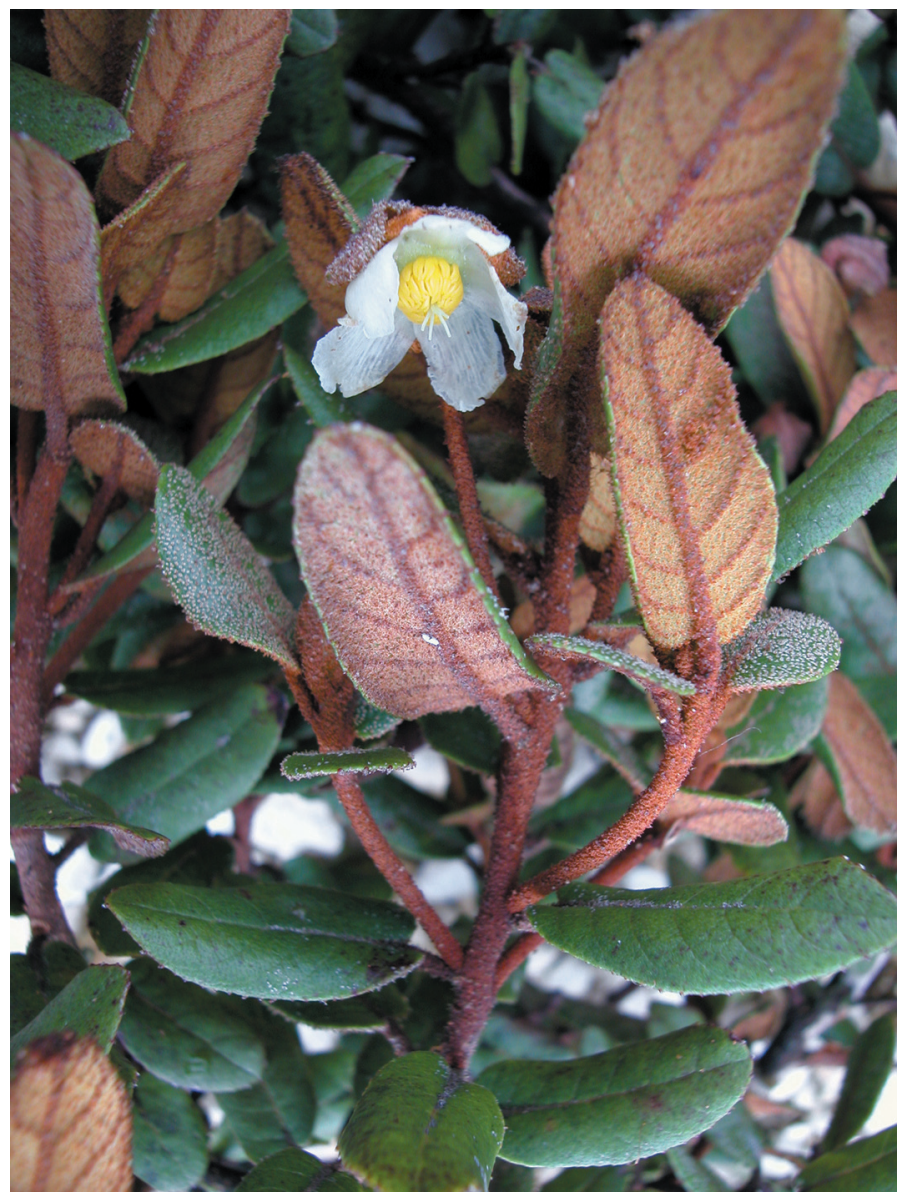

Fig. 4. Saurauia giluwensis (shown) often occurs with S. taylorii in mixed populations. The two species are the most common Saurauia in the Waile Creek area (Takeuchi, Towati \& Ama 20259).

2. Although the novelty is apparently referable to section Pleianthae subsection Setosae, infrageneric separations are very problematic in this genus (Smith 1941) and are likely to be redefined by future revision.

3. Saurauia taylorii is laxly furnished with conoid spines on lamina margins but is otherwise bifacially smooth. Nearly all other Papuasian congeners (with the notable exception of S. eburnea and S. plurilocularis) are hairy or scaly over at least some part of the lamina surface.

4. Saurauia emarginata (and to a lesser extent $S$. roemeri) are the taxa closest to $S$. taylorii, differing primarily in leaf size, shape, and indument. The inflorescence in S. emarginata also differs by being strictly solitary, while $S$. taylorii is uniflorous or monochasial. The three species can be separated with the following key: 
Lamina elliptic-obovate, 5-7 cm long, abaxial surfaces scaly; flowers solitary, erect. - Morobe Province, PNG . . . . . . . . . . . . . . . S. emarginata

Lamina elliptic, 10-12 cm long, abaxially strigose on veins; flowers dichasial, erect

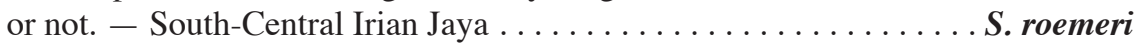

Lamina elliptic, elliptic-ovate, or obovate, $1.4-2.9(-3.4) \mathrm{cm}$ long, glabrous; flowers solitary or monochasial, nodding. - Enga Province, PNG . . . . . . S. taylorii

5. The leaf-blades of S. taylorii are the smallest of any Saurauia in Eastern Malesia, easily distinguishing the new species from congeners.

Additional specimen examined:

PAPUA NEW GuINEA. Enga Province: Takeuchi, Towati \& Ama 20087 (A, LAE).

\section{ACKNOWLEDGEMENTS}

The Kaijende Highlands Expedition was funded primarily by Conservation International and the Porgera Joint Venture (operators of the Porgera gold mine). My activities in Papuasian botany are supported by the National Science Foundation (grant DEB 0315930), the Arnold Arboretum, and the Herbaria of Harvard University. Parataxonomists Ali Towati and Demas Ama were my principal associates in the field.

\section{REFERENCES}

ABN-AMRO Morgans. 2006. Lihir gold. Deja vu - the transition continues. Report for investors. ABN-AMRO, Brisbane.

Barthlott, W., W. Lauer \& A. Placke. 1996. Global distribution of species diversity in vascular plants: towards a world map of phytodiversity. Erdkunde 50: 317-328.

Barthlott, W., J. Mutke, D. Rafiqpoor, G. Kier \& H. Kreft. 2005. Global centers of vascular plant diversity. Nova Acta Leop. n.s. 92 (342): 61-83.

Diels, L. 1922. Die Dilleniaceen von Papuasien. Bot. Jahrb. Syst. 57: 436-459.

Richards, S.J. (ed.). 2007. A rapid biological assessment of the Kaijende Highlands, Papua New Guinea. RAP Bulletin of Biological Assessment 45. Conservation International, Washington, DC. Smith, A.C. 1941. Studies of Papuasian plants, IV. J. Arnold Arbor. 22: 497-528.

Van Royen, P. 1982. The alpine flora of New Guinea. Volume 3: Taxonomic part Winteraceae to Polygonaceae. Cramer, Vaduz. 